\title{
The Current Zimbabwean Liquidity Crisis: A Review of its Precipitates
}

\author{
Banele Dlamini, Leonard Mbira \\ Lupane State University, Zimbabwe \\ dlabukhosi@gmail.com,lmbira@lsu.ac.zw,leombira@yahoo.com
}

\begin{abstract}
The liquidity crisis has beleaguered banks and has been bedeviling companies since 2009, after the introduction of the multi-currency system which has affected the Zimbabwean economic development. This research paper aims at investigating the causes of the liquidity crisis faced in the Zimbabwean economy. The study used survey design and researcher administered questionnaires in collecting data from the respondents located in Harare, Bulawayo, Gweru and Masvingo. Out of the 200 questionnaires issued, 150 were successfully completed and returned resulting in a response rate of $75 \%$. The study also used secondary data obtained from government agencies on export and import performance. SPSS AMOS was used to test the hypothesis raised and generate a path model determining the size and strength of the direct and indirect influence between the predictor variables and the downstream variable. The study identifies the following antecedents of liquidity crisis; public and investor confidence, country risk, and externalization of funds, illicit financial flows, and net export performance as significant drivers that have an effect on the current liquidity crisis. The results showed that the absence of the lender of last resort role by the central bank has no significant contribution to the liquidity crisis currently obtaining. It is recommended that the government focuses on the aforementioned antecedents in order to address the liquidity crisis.
\end{abstract}

Keywords: Liquidity crisis, risk, Monetary and financial policy, Zimbabwe

\section{Introduction}

The liquidity crisis which is differently referred to as credit crunch/financial crisis or meltdown is identified by a shortage of physical cash, lending funds, banks could be running out of cash, defaults, layoffs, bankruptcies and failing financial institutions among others. The liquidity crisis has been a problem in the Zimbabwean economy for quite some time. The country formally introduced multi- currency in 2009 as a strategic move to ease the economy which was choked by the Zimbabwean dollar. In the pre-"dollarization" period we find banks such Genesis, Tetrad, Royal, Trust and Allied collapsing. After the introduction of the multi-currency we find banks such as Interfin Bank, AfrAsia Bank Zimbabwe Limited, Renaissance merchant bank, Capital Bank and Royal Bank also going down the drainage. Liquidity risk is the epicenter of Zimbabwe economic recovery and it remains under the purview in the banking sector (Chagwiza, 2014), Liquidity crisis is the panacea to bank survival in the Zimbabwean economy (Chikoko and Pierre, 2012). The liquidity squeeze is directly felt by banks in the economy while other institutions and companies indirectly perceive the crisis. According to the Reserve Bank of Zimbabwe, (2016) as at 30 June 2016, the banking sector average prudential liquidity ratio was at $52.47 \%$ which is above the regulatory minimum requirement of $30 \%$. This paper investigates the causes of the liquidity crisis faced in the Zimbabwean economy. Unlike previous studies by Chikoko and Pierre (2012) and Chikoko (2014) which focused on management of liquidity risk among commercial banks in the Zimbabwe, this study focuses on liquidity crisis which is an under researched area in Zimbabwe. The paper is organized as follows; it briefly explains liquidity crisis, theoretical and conceptual framework of the study. A conclusion is made based on the findings of the study and recommendation to improve.

\section{Literature Review}

Definition of liquidity crisis: According to Borio \& Drehmann (2009) a liquidity crisis is the negative financial situation characterized by a sudden and prolonged evaporation of both market and funding liquidity, lack of cash flow, with potentially serious consequences for the stability of the financial system. It is also referred to as an acute drying up or shortage of liquidity in the real economy, which could show a fall in the prices of assets below their fundamental price, reduction in market participants or difficulties in trading assets (Amihud, Mendelson and Pedersen, 2013; Brunnermeier, 2009). 
Liquidity challenges: Liquidity crisis has its roots in the hyperinflation era and was first mostly pronounced in January 2004 and subsequently, the liquidity crisis then saw the collapse of the Century discount house on January 32004 (Iqbal et al., 2012; Muneer \& Rehman, 2012; Kairiza, 2009). The fall of Century Discount House led to the liquidity crisis especially to indigenous banks through a contagion effect which was later only partially mitigated through the prescription of the Troubled Bank Fund by the central bank. A decadelong economic collapse in Zimbabwe resulted in massive company closures and loss of jobs for the majority of Zimbabweans, seriously diminishing their ability to service their loans. Research by Mabvure, Gwangwava, Faitira, Clifford, \& Michael (2012) on non-performing loans in Zimbabwe, using a case study approach to certain banks, show that bank liquidity had been on a steady decline in Zimbabwe since 2009 owing to a significant rise in nonperforming loans. The limitation of their study was that it did not carry out a statistical test to prove the association between non-performing loans and the ensuing liquidity crisis. A study by Nhavira, Mugocha, \& Mudzonga (2013) on financial regulation and evaluation analysed the performance of all banks and equally found that high levels of nonperforming loans have negatively affected on the liquidity and capitalisation of the banks. No evidence of inferential analysis is shown.

Repatriation of export receipts is critical for liquidity, especially where a country has adopted foreign currency as its main currency as in the case of Zimbabwe which uses the United States dollar. Research by the Reserve Bank of Zimbabwe has shown that a number of institutions operating in Zimbabwe have externalised the US dollar in offshore accounts for speculative purposes and fear of the return of the Zimbabwean dollar or bond notes. The Reserve Bank of Zimbabwe (RBZ), in its monetary policy statement for January 2016 reported that in excess of $\$ 684$ million in funds were externalised by citizens in 2015 alone whilst in excess of 1.2 billion dollars exports receipts were externalised by firms. Research into the underlying causes of the liquidity crisis in Zimbabwe has also centred on export and import performance of the economy. Research by the RBZ (2016), IMF (2016), Kramarenko et al. (2012) and Mashakada (2016) indicates that the strengthening of the United States dollar as a result of a hike in interest rate led to a decline in commodity prices, a development that undermined export receipts which then ultimately negatively impacted on liquidity conditions in Zimbabwe. Given that Zimbabwe's economy is anchored on commodities such as gold, platinum, tobacco and recently diamond, among others, its economy suffers greatly when such commodities perform poorly on the international market. The stronger US Dollar (RBZ MPS, 2016; Chikoko, 2013) also led to increased demand for cheaper imports leading to higher outflows as a result of the switching effect of the appreciation. Closely linked with a dampened export performance and increased imports has been a worsening Balance of Payments (BOP) position. In its 2010 and 2016 country reports on Zimbabwe, the International Monetary Fund (IMF) noted that Zimbabwe had been experiencing a deteriorating BOP position that led to a reduction in the banks' foreign assets and culminated in structural liquidity pressures. The limited external inflows fuelled the already tight liquidity conditions in Zimbabwe. Similarly, Mashakada (2016a) identifies the deteriorating trade deficit resulting from a depreciating Rand as a significant contributor to the liquidity crisis. This is corroborated by Kararach et al. (2010) who, in their study on currency options in Zimbabwe, found that the 'dollarization' of the economy, despite stabilising a hyperinflationary pre-dollarization crisis emanating from economic mismanagement, triggered liquidity challenges. Liquidity generally should be hinged on good economic activity that generates output for both domestic and foreign consumption thus creating liquidity.

Depositor confidence in the banking sector is a critical ingredient for the liquidity health of any financial system. Tambudzai and Charumbira (n.d.), corroborated by Nhavira et al. (2013) and the RBZ (2016) identify a general lack of confidence in the financial sector as the main driver of hoarding of cash by the public resulting in cash circulating outside the banking system hence reducing the liquidity of the financial system. They associate the incentive to hoard cash to a motive to corruptly deal with the cash crisis possibly informed by the $2000-2008$ era practices when such tendencies were rampant and profitable. Other studies on the drivers of the liquidity crises in Zimbabwe have centred on the central bank's lender of last resort function that most literature view as critical for the strength of the financial sector. Makina (2009) and Nhavira et al. (2013) present that the inability of the central bank to play the lender of last resort function worsened the liquidity situation as banks were not open to interbank trade. Similarly, Mambondiani et al. (n.d.) in their study on corporate governance and bank performance in Zimbabwe, and the IMF country report on Zimbabwe (2010) noted that the absence of the lender of last resort function renders the banking sector illequipped to deal effectively with liquidity shocks. Add to this the unavailability of statutory reserves which 
have meant that the Zimbabwean banking system is not equipped to deal with any liquidity shocks owing to structural challenges. The unavailability of statutory reserves that are deposited with the RBZ limits the ability of the banking system to deal with liquidity challenges (IMF, 2010).

An important factor in preserving liquidity within the economy is limiting illicit financial flows. Economies that have strong liquidity postures are hinged on proper ring-fenced financial flows to curb leakage of liquidity. Research by the RBZ (2016) shows that there has been a lot of illicit financial flows that have exacerbated the liquidity situation as funds have been transferred out of the economy with rampant externalisation of funds mainly by individuals and companies in the extractive sectors. This is corroborated by Mashakada (2016) who identified rampant corruption, a lack of transparency and accountability grossly contributing to the current crisis. The connection between country risk and liquidity has been proven by a study by the IMF (2010) which showed that the obtaining level of country risk in Zimbabwe precludes foreign liquidity support. The existing indigenisation laws are not conducive for investor support as they are over-inclined to domestic expropriation. Zimbabwe has a history of the volatile takeover of a business establishment which scares away foreign investors. Fuelling the already high and volatile country risk is the long dragging of external arrears which puts pressure on the liquidity conditions as international finance institutions are reluctant to support Zimbabwe in the face of long-standing arrears (IMF, 2016; Berrospide, 2013). Clearing such arrears would improve relations with international finance institutions and hence resumption of financial support from such institutions. Mashakada (2016) posit that the crisis is worsened by the mopping up of liquidity by the Zimbabwean government through internal borrowings stressing that public borrowing by the government, which has issued in excess of 2 billion treasury bills to the banking system and continued to roll them over upon maturity has moped up liquidity.

Conceptual framework: From the above review we develop the following model informed by the contributions of these earlier researchers.

\section{Figure 1: Conceptual model}

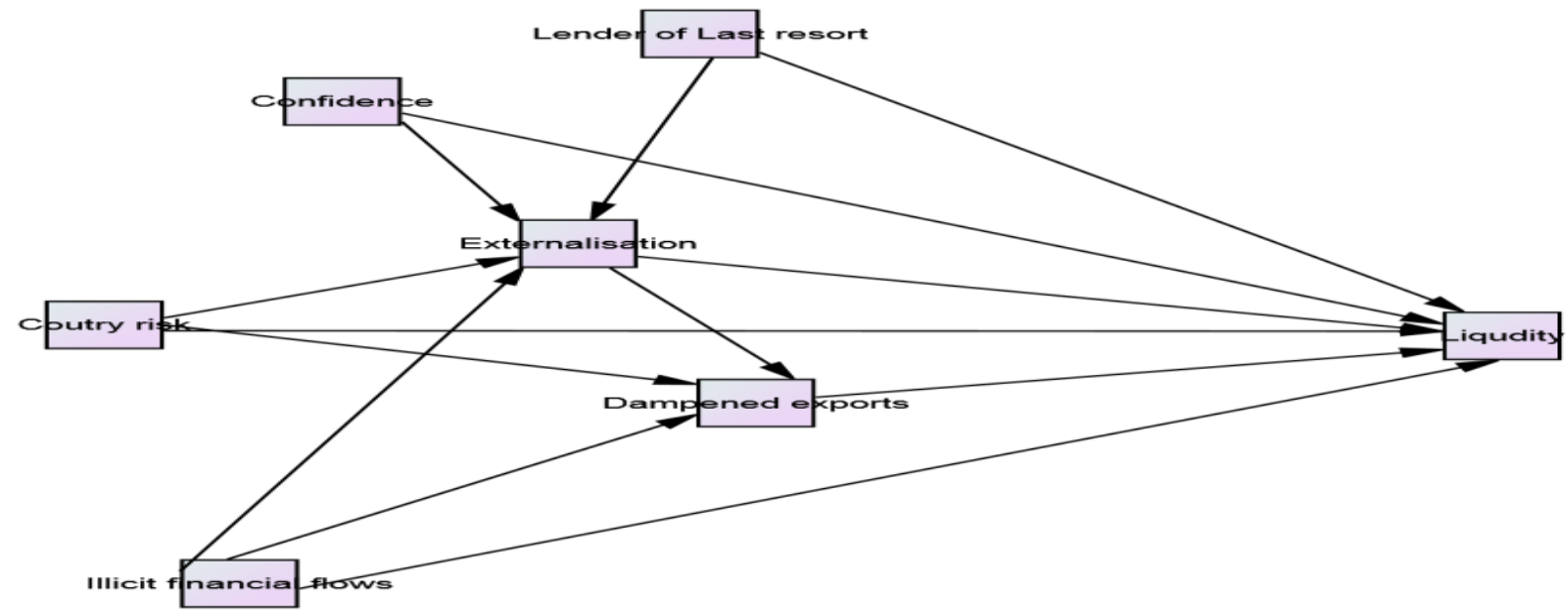

Source: Own Formulation

\section{Methodology}

The aim of this study was to identify determinants of the liquidity crisis obtaining in Zimbabwe. The study used a survey for data collection targeting bank employees and captains of industry as well as the banking 
public from Harare, Bulawayo, Gweru and Masvingo cities. A survey questionnaire was used as a research tool for this study because of the standardized nature of the data sought and the need to afford the respondents reference to their records and a chance for a considered response. A total of 200 questionnaires were administered and 150 were successfully completed resulting in a response rate of $75 \%$.The study also used secondary data obtained from government agencies on export and import performance. The study focused mainly on the post "dollarization" era from 2009 to date (2017). The hypothesis was collapsed into two main categories as:

$\mathbf{H O}_{1}$ : There is no direct relationship between any of confidence, country risk, illicit financial flows, lender of last resort, externalization, net export performance and the liquidity level.

$\mathbf{H O}_{2}$ : There is no indirect relationship between any of confidence, country risk, illicit financial flows, lender of last resort and the liquidity level.

The study used SPSS AMOS to conduct structural equation modeling to test the two propositions above and generate path modeling to find the size and strength of the direct and indirect influence between the predictor variables and liquidity. The test is conducted at a 5\% significance level.

\section{Results}

Table 1: Goodness of fit

\begin{tabular}{ll} 
Chi-square & 2.224 \\
Degrees of freedom & 1 \\
Probability level & 0.136 \\
\hline
\end{tabular}

The model results show an overall Chi-square value of 2.24 as shown in table 1 above indicating that even though the model was a reduced model it fits the data just as does a just-identified model. Wuensch (2016) present that a low model chi-square value is desirable as it indicates a close to perfect fit with relevant model paths. This not significant chi-square of 2.24 from the results thus proves that the fit between the data and our over-identified model does not significantly deviate from the fit between the saturated model and the data. A CMIN/DF of 2.2 was achieved demonstrating that the dropped paths have not definitely affected the model fit as it is below three as presented by Wuensch (2016). The model had a goodness of fit index (GFI) of 0.996 indicating that $99.6 \%$ of the variance in the sample variance-covariance matrix is accounted for by the model.

Correlation analysis: The correlation matrix shows that the upstream variables have low acceptable correlation levels among themselves. The lowest correlation value was 0.012 obtained between country risk and lender of last resort function whilst the highest was -0.505 which was between public and investor confidence in the financial sector and illicit financial flows. Table 2 below indicates the respective correlations among the variables.

Table 2: Correlations

\begin{tabular}{llll}
\hline & & & Estimate \\
\hline Country risk & $<-->$ & Illicit financial flows & 0.336 \\
Confidence & $<->$ & Illicit financial flows & -0.505 \\
Illicit financial flows & $<-->$ & Lender of last resort & 0.134 \\
Confidence & $<->$ & Lender of last resort & 0.104 \\
Confidence & $<-->$ & Country risk & -0.331 \\
Country risk & $<-->$ & Last resort & 0.012 \\
\hline
\end{tabular}

Path diagram analysis and results: The hypothesized and tested direct and indirect relationship between the antecedents and liquidity with their respective standardized estimates are as presented below in figure 2.The model tested the impact of public and investor confidence, country risk, the absence of the lender of last resort and illicit financial flows on the level of liquidity in the economy. There are two intermediation variables in the model (externalization of funds and net export performance) 
Figure 2: Path diagram analysis and results

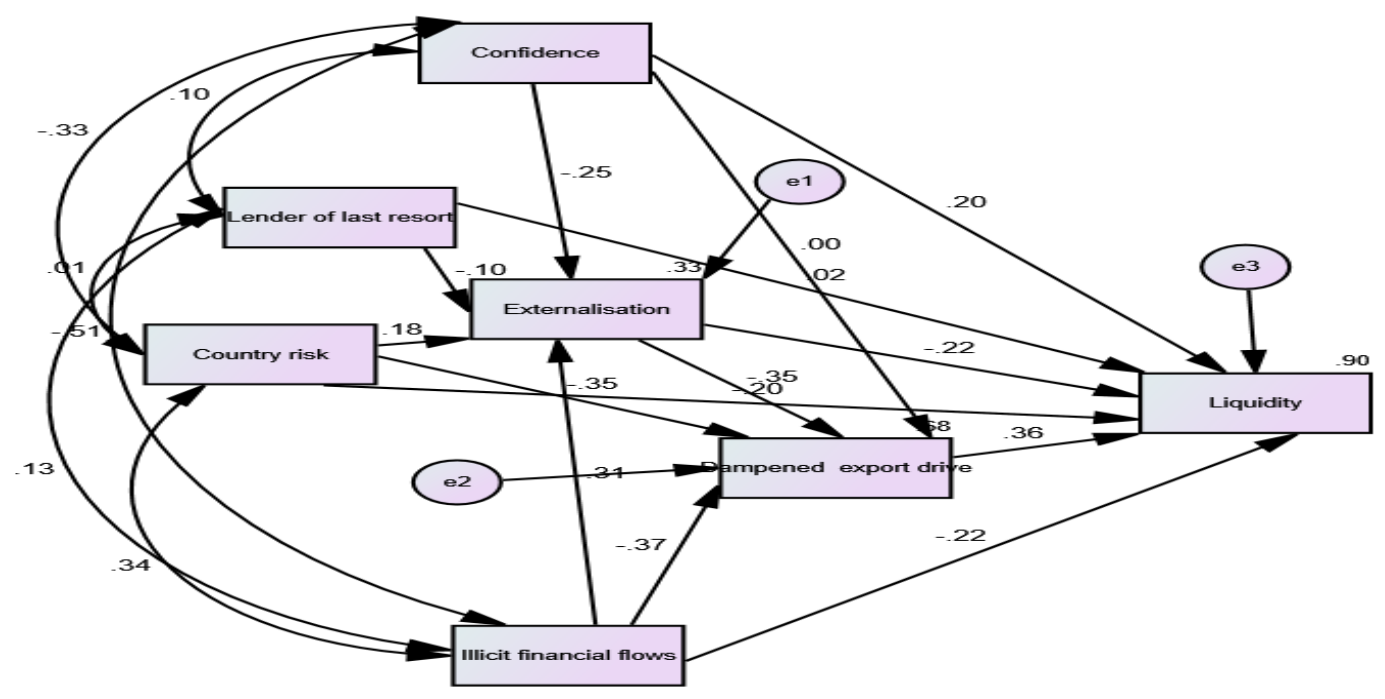

Table 3: Regression weights

\begin{tabular}{|c|c|c|c|c|c|c|c|c|}
\hline & & & & Estimate & S.E. & C.R. & $\mathbf{P}$ & Label \\
\hline externalization & & $<---$ & confidence & -.474 & .155 & -3.056 & .002 & \\
\hline externalization & & $<---$ & Country risk & .202 & .082 & 2.447 & .014 & \\
\hline externalization & & $<---$ & Illicit financial flows & .306 & .081 & 3.780 & $* * *$ & \\
\hline externalization & & $<---$ & Lender of last resort & -.271 & .186 & -1.456 & .145 & \\
\hline $\begin{array}{l}\text { Net } \\
\text { performance }\end{array}$ & export & $<---$ & Country risk & -.304 & .044 & -6.877 & $* * *$ & \\
\hline $\begin{array}{l}\text { Net } \\
\text { performance }\end{array}$ & export & $<---$ & Illicit financial flows & -.284 & .043 & -6.584 & $* * *$ & \\
\hline $\begin{array}{l}\text { Net } \\
\text { performance }\end{array}$ & export & $<---$ & confidence & -.006 & .083 & -.073 & .942 & \\
\hline $\begin{array}{l}\text { Net } \\
\text { performance }\end{array}$ & export & $<---$ & externalization & -.268 & .043 & -6.281 & $* * *$ & \\
\hline Liquidity & & $<---$ & Illicit financial flows & -.091 & .016 & -5.844 & $* * *$ & \\
\hline Liquidity & & $<---$ & externalization & -.092 & .015 & -6.181 & $* * *$ & \\
\hline Liquidity & & $<--$ & Country risk & -.094 & .016 & -6.016 & $* * *$ & \\
\hline Liquidity & & $<---$ & Lender of last resort & .017 & .030 & .557 & .577 & \\
\hline Liquidity & & $<---$ & confidence & .162 & .026 & 6.247 & $* * *$ & \\
\hline Liquidity & & $<--$ & Net export performance & .194 & .025 & 7.648 & $* * *$ & \\
\hline
\end{tabular}

Regression weights: Using the most likelihood estimation method for predicting the size and strength of the hypothesized relationships, the results show that 
- There is a strong significant negative relationship between the confidence the public and investors have on the country's banking system and the level of externalization of funds outside the country's banking system with an unstandardized regression weight of -0.474 and a p-value of 0.002 indicating that confidence is an important factor in funds retention and remittance following international transactions. Illicit financial flows have a significant impact on liquidity. Results show a weak but significant relationship between the two with a coefficient of -0.092 and a p-value of 0.00 . This implied that illicit financial flows have cost the nation in terms of the obtaining high levels of liquidity challenges in the financial sector.

- Externalization and Country risk had a significant negative impact on liquidity. The impact of externalization of funds and high country risk has been a reduction in liquidity in the economy as shown by a coefficient of -0.92 and -0.094 for the two factors respectively.

- Lender of last resort function has an insignificant role in the current liquidity crisis. The results show a weight of 0.017 at a p-value of 0.577 indicating that the current liquidity crisis in Zimbabwe cannot be attributed to the absence of a lender of last resort role by the reserve bank though public and investor confidence in the financial sector as well as net export performance had an impact on the liquidity levels.

Results indicate that a general lack of public confidence in the financial sector together with low export performance contributed significantly to the current liquidity crisis.

The indirect (mediated) effect of the determinants on externalization, net export performance and liquidity are presented indicated in table 5 below. The indirect impact of confidence on liquidity is .067 . Due to the indirect (mediated) effect of confidence on liquidity, when confidence goes up by 1 , liquidity goes up by 0.067. This is in addition to any direct (unmediated) effect that confidence may have on liquidity. Other determinants indirect effects are also indicated.

Table 4: Indirect Effects

\begin{tabular}{lllllll}
\hline & Confidence & $\begin{array}{l}\text { Illicit } \\
\text { financial flows }\end{array}$ & $\begin{array}{l}\text { Country } \\
\text { risk }\end{array}$ & $\begin{array}{l}\text { Lender } \\
\text { of last } \\
\text { resort }\end{array}$ & Externalization & $\begin{array}{l}\text { Net export } \\
\text { performance }\end{array}$ \\
\hline Externalization & .000 & .000 & .000 & .000 & .000 & .000 \\
$\begin{array}{l}\text { Net export } \\
\text { performance }\end{array}$ & .127 & -.082 & -.054 & .073 & .000 & .000 \\
Liquidity & .067 & -.099 & -.088 & .039 & -.052 & .000 \\
\hline
\end{tabular}

The results show that the mediated effects of the antecedents have low coefficients indicating that the determinants affect liquidity more without intermediation than they do with intermediation.

\section{Conclusion}

The severe liquidity challenges currently bedeviled the Zimbabwean economy has become a serious threat to the survival of the economy. Whilst many theories have been presented at various fora (even though without empirical support) and various arguments presented by government agencies, multilateral institutions, industries and economists alike on the major causes of the current liquidity crisis in Zimbabwe it still remained a mystifying phenomenon. This study recognizes the importance of a sound financial system for economic development. The study identifies public and investor confidence, country risk, illicit financial flows, externalization of funds and net export performance as significant drivers of the current liquidity crisis. However, the results indicated that the absence of the lender of last resort role by the reserve bank had no significant contribution to the liquidity crisis currently obtaining. The implications of this study are that to address the current liquidity crisis, the government should focus on addressing public and investor confidence, country risk, illicit financial flows, externalization of funds and net export performance which the study identifies to be the very underlying drivers behind the crises. Whilst addressing the lender of last resort function by the reserve bank could enhance liquidity, more efforts should be focused on the aforementioned 
drivers. There is scope for future research to possibly consider the impact of the current liquidity crisis and explore deeper into its nature.

\section{References}

Amihud, Y., Mendelson, H. \& Pedersen, L. H. (2012). Market Liquidity Asset Pricing, Risk, and Crisis. Cambridge: Cambridge University Press.

Berrospide, J. (2013). Bank Liquidity Hoarding and the Financial Crisis: An Empirical Evaluation (Finance and Economics Discussion Series Divisions of Research \& Statistics and Monetary Affair No. 2013-3). Washington, D.C.

Borio, C. \& Drehmann, M. (2009). Assessing the Risk of Banking Crises - Revisited. BIS Quarterly Review, 3, 29-46. Retrieved from http://www.bis.org/publ/qtrpdf/r_qt0903e.pdf.

Brunnermeier, M. K. (2009). Deciphering the Liquidity and Credit Crunch 2007-2008. Journal of Economic Perspectives, 23(1), 77-100. https://doi.org/10.1257/jep.23.1.77.

Chagwiza, W. (2013). Liquidity Derivatives as Solution to Zimbabwean Economic Liquidity Problems. Global Advanced Research Journal of Economics, Accounting and Finance, 2(3), 67-72.

Chikoko, L. (2014). Potential Sources of Zimbabwe Banks Illiquidity After Dollarisation. Journal of Contemporary Issues in Business Research, 3(1), 41-51.

Chikoko, L. \& Pierre, L. R. (2012). Zimbabwe Commercial Banks Liquidity Management in the Hyperinflation Environment. African Journal of Business Management, 6(48), 11787-11796. https://doi.org/10.5897/AJBM12.1314.

Clemens, B. M. \& Moss, T. (2005). Costs and Causes of Zimbabwe's Crisis. Center for Global Development, (July 2005).

Dube, H. \& Matanda, E. (2015). The Downfall of the Micro Lending Businesses in Zimbabwe: Causes and Remedies. International Review of Research in Emerging Markets and the Global Economy (IRREM) An Online International Research Journal, 1(4), 2311-3200. Retrieved from www.globalbizresearch.org.

Dullien, S., Davies, R., Huizenga, C., Kotte, D. J., Cintra, M., Peates, D. \& Zattler, J. (2010). The Financial and Economic Crisis of 2008-2009 and Developping Countries. (S. Dullien, D. J. Kotte, A. Marquez, \& J. Priewe, Eds.), United Nations Conference on Trade and Development and Hochschule fur Technik und wWrtschaft Berlin. UNCTAD. Retrieved from http://unctad.org/en/Docs/gdsmdp20101_en.pdf.

Dzingirai, C. (2014). Determinants of Bank Failures in Multiple-Currency Regime in Zimbabwe (2009-2012). International Journal of Economics and Finance, 6(8), 229-246. https://doi.org/10.5539/ijef.v6n8p229.

International Monetary Fund. (2016). Staff Report for the 2016 Article IV Consultation. IMF Country Report No.16/110, (16). https://doi.org/1AGOEA2015002.

Kairiza, T. (2009). Unbundling Zimbabwe's Journey to Hyperinflation and Official Dollarization (GRIPS Policy Information Center No. 9-12). Tokyo. Retrieved from www.grips.ac.jp/r-center/wpcontent/uploads/09-12.pdf.

Kararach, G., Kadenge, P. \& Guvheya, G. (2010). Currency Reforms in Zimbabwe: An Analysis of Possible Currency Regimes (10). African Capacity Building Foundations. TheAfricanCapacityBuildingFoundation.

Kramarenko, V., Engstrom, L., Verdier, G., Fernandez, G., Oppers, S. E., Hughes, R. \& Coats, W. (2010). Zimbabwe: Challenges and Policy Options after Hyperinflation. International Monetary Fund (10th-3rd ed.). Washington, D.C.: International Monetary Fund. Retrieved from http://www.abaz.co.zw/pdf/International Monetary Fund/Zimbabwe - Challenges and Policy Options after Hyperinflation.pdf.

Laeven, L., Valencia, F., Cerutti, E., Claessens, S., Cortavarria-Checkley, L., Dohlman, P. \& Wiegand, J. (2012). Resolution of Banking Crises: The Good, the Bad, and the Ugly, (August). https://doi.org/10.5089/9781455201297.001.

Mabvure, J., Gwangwava, E., Faitira, F., Clifford, M. \& Michael, K. (2012). Non Performing loans in Commercial Banks : A case of CBZ Bank Limited In Zimbabwe. Interdiscriplinary Journal of Contemporary Research in Business, 4(7), 467-488.

Makina, D. (2009). Recovery of the Financial Sector and Building Financial Inclusiveness (Comprehensive Economic Recovery in Zimbabwe). UNDPs Comprehensive Economic Recovery in Zimbabwe Working Paper Series (Vol. 5). 
Mambondiani, B. L., Zhang, Y. \& Arun, T. (2014). Corporate Governance and Bank Performance : Evidence from Zimbabwe, 1-32.

Mangudya, J. (2016). Press Statement Measures to Deal with Cash Shortages whilst Simultaneously Stabilising and Stimulating. Harare: Reserve Bank of Zimbabwe.

Mashakada, T. (2016a). Alternative solutions to the liquidity, cash crisis - The Zimbabwe Independent. Zimbabwe Independent. Retrieved from http.

Mashakada, T. (2016b). The liquidity-cum-cash challenges in Zimbabwe A fiscal policy crisis. A Voice for the Voiceless. Retrieved from http/www.

Mudzingiri, C. (2013). The Impact and Lessons of the 2008 Global Financial Crisis to Zimbabwe. Dubai: International Business and Social Sciences Research. https://doi.org/10.5901/mjss.2014.v5n27p333.

Muneer, S. \& Rehman, S. U. (2012). Materialization of Behavioral Finance and Behavioral Portfolio Theory: A Brief Review. Journal of Economics and Behavioral Studies, 4(8), 431-435

Munzara, A. T. (2015). Escaping Deflation In Zimbabwe: The Role Of Fiscal And Monetary Policies. IOSR Journal of Economics and Finance, 6(6), 23-25. https://doi.org/10.9790/5933-06612325.

Mzumara, M. (2012). An Overview of Zimbabwe' S Macroeconomic Environment. International Journal of Economic Research, 3(1), 33-69.

Ngwenya, B. \& Chiwawa, D. (2016). Impact of liquidity crisis on bank's response towards corporate social responsibility: A Case Study of Commercial Bank of Zimbabwe ( CBZ ) Ltd Harare period ( 20092014 ). International Journal of Research and Reports, 2(2), 55-64.

Nhavira, J. D. G., Mugocha, E. \& Mudzonga, E. (2013). Financial Regulation and Supervision in Zimbabwe : An Evaluation of Adequacy and Options. Financial Regulation and Supervision in Zimbabwe. Harare: Zimbabwe Economic Policy Analysis and Research Unit. Retrieved from http://elibrary.acbfpact.org/acbf/collect/acbf/index/assoc/HASH3ed8.dir/Financial Regulation.pdf.

Reserve Bank of Zimbabwe. (2016). Monetary policy statement: 2016. zimbabwe. Retrieved from http://www.rbz.co.zw/assets/monetary-policy-statement-january-2016.pdf.

Tambudzai, Z. \& Charumbira, M. (n.d.). Cash Shortages in Zimbabwe : Any Prospect for Solutions ? The Dyke, $0(1), 22-31$.

Wuensch, K. L. (2016). Conducting a Path Analysis With SPSS / AMOS. Retrieved from core.ecu.edu/psyc/wuenschk/MV/SEM/Path-SPSS-AMOS.pdf. 